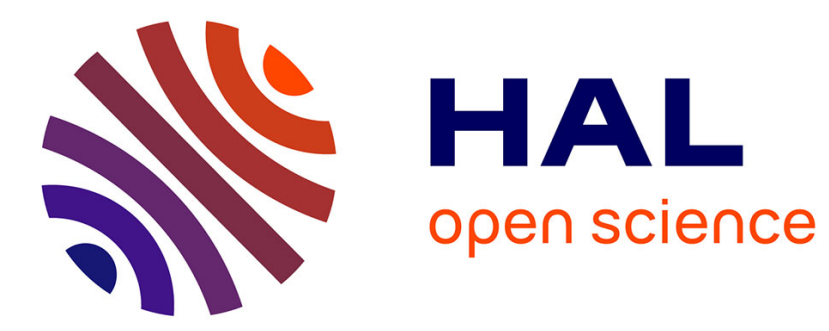

\title{
Precision design of ethylene- and polar-monomer-based copolymers by organometallic-mediated radical polymerization
}

Anthony Kermagoret, Antoine Debuigne, Christine Jérôme, Detrembleur

Christophe

\section{To cite this version:}

Anthony Kermagoret, Antoine Debuigne, Christine Jérôme, Detrembleur Christophe. Precision design of ethylene- and polar-monomer-based copolymers by organometallic-mediated radical polymerization. Journée du département de chimie Université de Liège, Jul 2014, Liège, Belgium. 2014. hal-01345432

\section{HAL Id: hal-01345432 \\ https://hal.science/hal-01345432}

Submitted on 13 Jul 2016

HAL is a multi-disciplinary open access archive for the deposit and dissemination of scientific research documents, whether they are published or not. The documents may come from teaching and research institutions in France or abroad, or from public or private research centers.
L'archive ouverte pluridisciplinaire HAL, est destinée au dépôt et à la diffusion de documents scientifiques de niveau recherche, publiés ou non, émanant des établissements d'enseignement et de recherche français ou étrangers, des laboratoires publics ou privés. 


\section{焉}

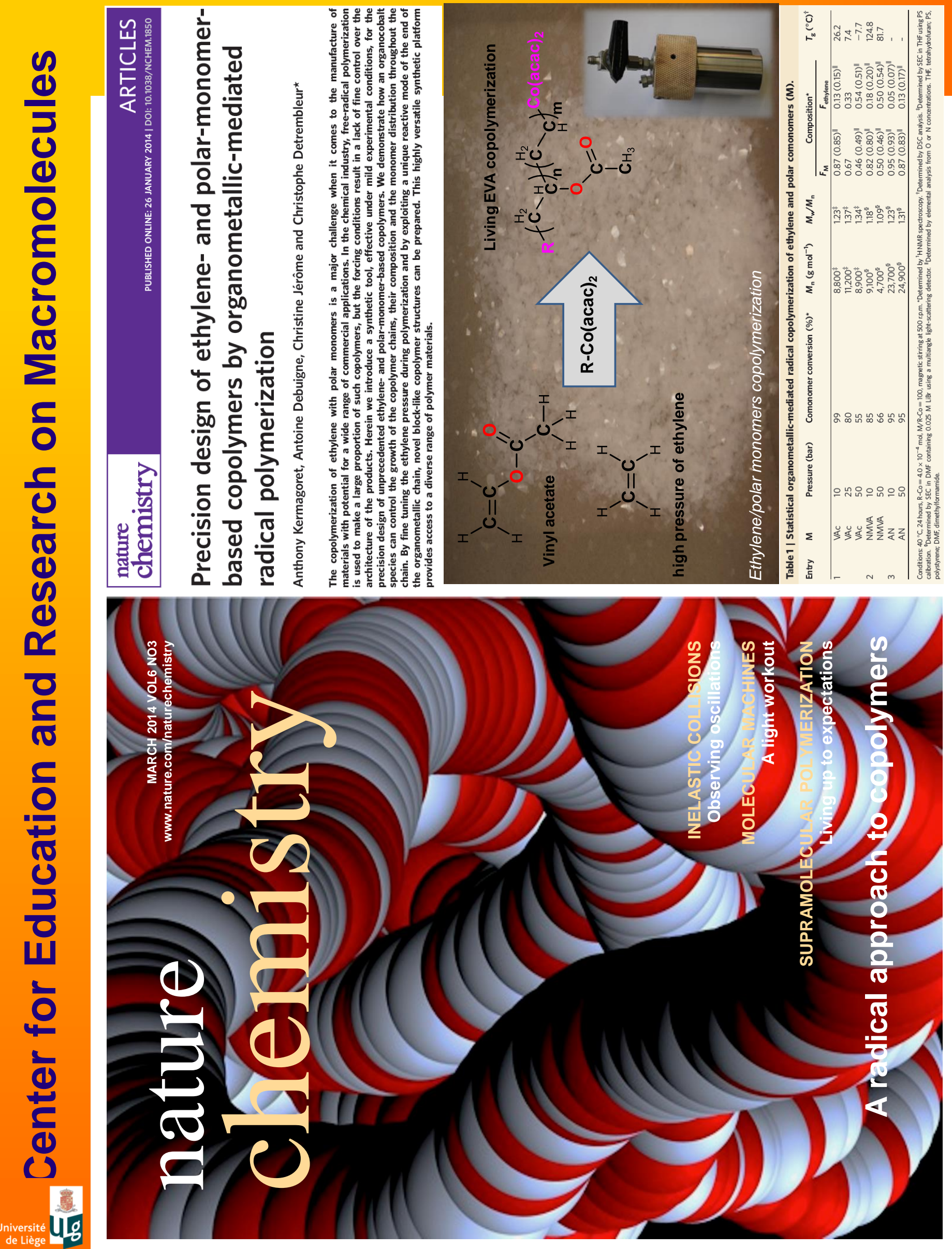

